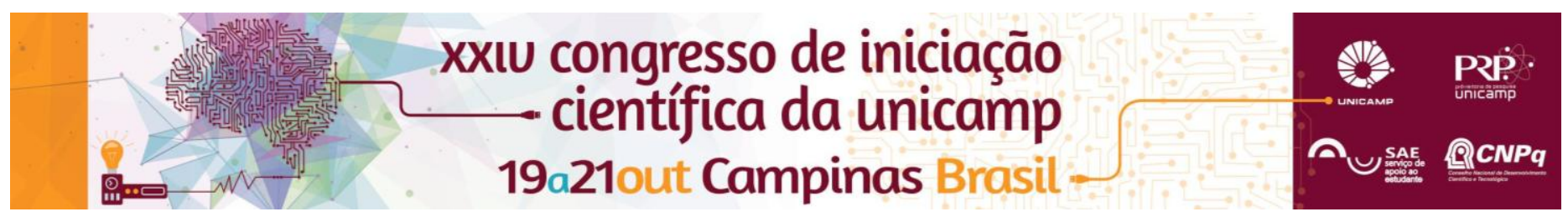

\title{
Desinfecção de água contaminada por E. coli utilizando eletrodos de TiO2 sob irradiação com um simulador solar
}

\author{
Eveline Ramos*, Fernando P. Candello, José R. Guimarães, Claudia Longo
}

\begin{abstract}
Resumo
A desinfecção de água contendo $\mathrm{E}$. coli está sendo investigada utilizando eletrodos de TiO2 $(8 \mathrm{~cm} 2)$ irradiados com simulador solar em reatores com capacidade para $25 \mathrm{~mL}$. Em geral, a quantidade de bactérias não foi alterada no escuro; porém, diminuiu uma ordem de grandeza em soluções irradiadas (desinfecção por fotólise). O tratamento foi mais eficaz na presença do TiO2 (fotocatálise heterogênea, $\mathrm{FH}$ ), pois a irradiação causa uma separação de cargas no TiO2 que gera radicais hidroxila, espécies que atacam a membrana celular dos microorganismos. Incluindo um fio de $\mathrm{Pt}$ como contra-eletrodo, a conexão com uma célula solar tornou o processo de $\mathrm{FH}$ eletroquimicamente assistido, o que minimizou a recombinação das cargas fotogeradas e resultou em maior eficiência de desinfecção da água.
\end{abstract}

\section{Palavras-chave:}

Fotocatálise heterogênea, TiO2, desinfecção de água.

\section{Introdução}

As questões relacionadas à qualidade da água ainda são fundamentais em nossa sociedade. De acordo com a Organização Mundial de Saúde, cerca de dois milhões de pessoas morrem por ano em decorrência de água contaminada. Para mudar esta situação, é necessário garantir o tratamento e desinfecção da água. No Brasil, a forma de desinfecção mais comum é a cloração, um processo de alta eficiência e baixo custo; no entanto, pode reagir com substâncias presentes nas águas e formar trialometanos e subprodutos tóxicos. ${ }^{(1)}$ Para evitar a supercloração, os pesquisadores têm investigado o uso de métodos baseados na formação in situ de radicais hidroxila, espécies reativas capazes de oxidar poluentes que não são removidos pelas técnicas convencionais de tratamento de água. Estes métodos, denominados Processos Oxidativos Avançados (POA), podem inativar microorganismos através do ataque à membrana celular, ${ }^{(1)}$ e possibilitam minimizar o uso de cloro para desinfecção da água.

Em nosso grupo de pesquisa, estamos investigando o aproveitamento da radiação solar para promover 0 tratamento da água por fotocatálise heterogênea $(F H)$ utilizando eletrodos semicondutores. Neste tipo de POA, quando o semicondutor é irradiado, um elétron é promovido para a Banda de Condução e deixa uma lacuna de carga positiva na Banda de Valência; ao reagir com moléculas de água, as lacunas geram radicais hidroxila na superfície do fotocatalisador. Ao incluir um contra-eletrodo no sistema $\mathrm{FH}$, o processo pode ser eletroquimicamente assistido (FHE) aplicando-se um potencial elétrico positivo ao fotoeletrodo, o que pode ser obtido pela conexão de uma célula solar. Com isso, diminui-se a recombinação elétron-lacuna e o processo torna-se muito mais eficiente. Esta estratégia foi utilizada em nosso grupo para degradação de fenol, do corante Rodamina-B e do hormônio etinilestradiol. ${ }^{(2)}$ Os excelentes resultados obtidos nos motivou a utilizar este sistema para a desinfecção de água contaminada por $E$. coli, bactéria utilizada como indicador biológico da qualidade da água. ${ }^{(1)}$

\section{Resultados e Discussão}

Os eletrodos foram produzidos através da deposição de um filme de partículas de $\mathrm{TiO}_{2}$ sobre vidro-FTO. Os experimentos para avaliar a atividade bactericida foram realizados em duplicatas, em meio constituído por $E$. coli em água de diluição $\left(\mathrm{KH}_{2} \mathrm{PO}_{4}\right.$ 0,3 mmol L-1 e $\mathrm{MgCl}_{2}$ 0,2 mmol L $L^{-1}$ ) nas configurações: $\mathrm{FH}$ (eletrodo de $\mathrm{TiO}_{2}$ sob irradiação); $\mathrm{FHE}$ (eletrodo de $\mathrm{TiO}_{2}$ e contra-eletrodo de platina conectados externamente a uma célula solar); fotólise (sem fotocatalisador, sob irradiação); controle (sem fotocatalisaor, no escuro). A concentração de bactérias na solução recém-preparada (entrada) e após o tratamento foi determinada com o método Colilert®.

Tabela 1. Tratamento de suspensões com diferentes concentrações de entrada de $E$. coli em "água de diluição" (25 mL) com eletrodos de $\mathrm{TiO}_{2}(8,0 \pm 0,5) \mathrm{cm}^{2}$, sob irradiação com simulador solar $\left(130 \mathrm{~mW} / \mathrm{cm}^{2}\right) \mathrm{em}$ diferentes tempos, a $(26 \pm 3)^{\circ} \mathrm{C}$.

\begin{tabular}{|c|c|c|c|c|c|}
\hline $\mathbf{t}$ & \multicolumn{5}{|c|}{ Concentração (NMP/100 mL) } \\
\cline { 2 - 6 } (h) & Entrada & Controle & Fotólise & FH & FHE \\
\hline 1 & $(1,7 \pm 0,6) \cdot 10^{7}$ & $(1,5 \pm 0,4) \cdot 10^{7}$ & $(4 \pm 4) \cdot 10^{6}$ & $(3 \pm 3) \cdot 10^{6}$ & $(8 \pm 3) \cdot 10^{3}$ \\
\hline 2 & $(4 \pm 1) \cdot 10^{7}$ & $(4 \pm 1) \cdot 10^{7}$ & $(6 \pm 3) \cdot 10^{6}$ & $(1,0 \pm 0,5) \cdot 10^{5}$ & $(8 \pm 4) \cdot 10^{4}$ \\
\hline 3 & $(3 \pm 1) \cdot 10^{8}$ & $(3,6 \pm 0,7) \cdot 10^{8}$ & $(2 \pm 2) \cdot 10^{4}$ & 5,0 & $<5,0$ \\
\hline
\end{tabular}

A configuração FHE apresentou a maior eficiência de desinfecção. A população do controle manteve-se estável, indicando que a redução da quantidade de bactérias foi provocada pelos tratamentos empregados.

\section{Conclusões}

Os resultados obtidos são promissores e indicam que o sistema para tratamento de água por FHE que estamos desenvolvendo é capaz de inativar $E$. coli em água.

\section{Agradecimentos}

CNPq, CAPES, FAPESP e INOMAT.

\footnotetext{
Libânio, M. Fundamentos de qualidade e tratamento de água. $2^{\mathrm{a}}$ ed Campinas, Editora Átomo, 2008

${ }^{3}$ Oliveira, H.G, Ferreira, LH., Bertazolli, R., Longo, C. Water Res. 2015, 72 305 .
} 